\title{
FORUM
}

\section{A Review of Prey Choice in Bembicine Sand Wasps (Hymenoptera: Sphecidae)}

\author{
Howard E. Evans \\ Dept. Bioagricultural Sciences and Pest Management,Colorado State University, \\ Fort Collins, Colorado 80523-1177,USA
}

Neotropical Entomology 31(1): 001-011 (2002)

Revisão Sobre a Escolha de Presa por Vespas Bembicineas (Hymenoptera: Sphecidae)

\begin{abstract}
RESUMO - As presas de 132 espécies de vespas Bembicini (Hymenoptera) que foram estudadas são revisadas. Cerca de três quartos das espécies predam Diptera e acredita-se que a predação de moscas é um evento ancestral no grupo. Onze espécies predam, além de Diptera, ocasionalmente ou regularmente espécies de Lepidoptera, Hymenoptera, Neuroptera, Odonata e/ou Homoptera. Entretanto, outras 21 espécies pertencentes a cinco gêneros predam espécies das cinco ordens mencionadas, mas não predam Diptera. Especula-se q ue esse fato represente uma progressão evolucionária, quando populações de vespídeos foram expostas à escassez de dípteros no passado e foram obrigadas a ampliar o foco incluindo presas pertencentes a outros grupos de insetos voadores. Esse comportamento inicialmente aprendido foi revigorado geneticamente ao longo do tempo evolucionário para produzir a radiação atual no número de presas dentro do grupo.
\end{abstract}

PALAVRAS-CHAVE: Insecta, Bembicini, escolha de presa, evolução comportamental.

\begin{abstract}
The prey of 132 species of Bembicini (Hymenoptera) that have been studied is reviewed. About three quarters of the species prey on Diptera, and it is believed that fly predation is ancestral in the group. Eleven species make occasional or regular use of other insects as prey in addition to Diptera (Lepidoptera, Hymenoptera, Neuroptera, Odonata, and/or Homoptera), while 21 species of five genera prey on insects of these same five groups with no use of Diptera. It is hypothesized that this represents an evolutionary progression, whereby populations have experienced shortages of dipterous prey in the past and have broadened their sensory focusing to include other groups of flying insects. Behavior initially learned has, over time, been reinforced genetically to produce the currently observed radiation in prey choice within the group.
\end{abstract}

KEY WORDS: Insecta, Bembicini, prey choice, behavioral evolution.

The evolution of divergence in food choice within major taxa of insects has been a topic of research and discussion for many years (e.g., Brues 1936, Linsley 1958, Shaw 1988). Bernays \& Wcislo (1994), in a review of sensory capabilities and resource specialization, cite a striking example from Rothschild and Clay (1961) relating to fleas (Siphonaptera). The hen flea has been recorded from over 65 species of birds in Britain, whereas another species of the same genus (Ceratophyllus) occurs only on the crow. Examples such as this pose a challenge to students of the evolution of trophic behavior.

Digger wasps (Hymenoptera: Sphecidae), considered as a group, provide similar examples. The small wasp Lindenius columbianus (Kohl) (Crabroninae) provisions its nests with insects of four major groups: Diptera, Homoptera, Hemiptera, and Hymenoptera (Miller \& Kurczewski 1975). Individual cells in a nest may contain members of each of these groups, which, though they differ greatly in morphology, evidently provide suitable food for the larvae. An example of an even more extreme specificity is provided by members of the genus Microbembex (Bembicinae), which take dead or disabled members of at least 14 orders of insects and arachnids (Evans 1966).

In contrast, species of Aphilanthops (Philanthinae) prey only on alate queen Formica ants, and the females are actively provisioning their nests during the few weeks when these ants are on the wing. Members of the related genus Clypeadon prey on worker harvester ants (Pogonomyrmex) and will even enter the nests of these formidable ants to obtain prey (Evans 1962). For a broad review of prey diversity in Sphecidae, see Chapter 3 in O'Neill (2001).

It must be pointed out that prey choice is not limited by larval requirements. Evidence suggests that many if not all species of sand wasps will develop successfully on whatever 
prey is presented to them.

The group I wish to consider here, the sand wasps (Bembicini), consists of relatively large wasps with prominent eyes that occupy much of the head and robust thoraces that are largely filled with flight musculature. These are superb aerial predators: they are swift, they hover and turn rapidly, they grasp and sting their prey quickly, then hold it tightly as they proceed to a nest in the soil, the location of which they have learned through orientation flights (Van Iersel 1952). Within the nest, larvae consume the prey provided (the adults feed on nectar). Literature on sand wasp biology goes well back into the nineteenth century. Many of the earlier reports have been reviewed by Nielsen (1945), Evans (1966), Bohart \& Menke (1976), and others. This review stresses recent major reports bearing on prey choice. I review this subject in the hope of gaining insights as to the role ecological factors may play in prey choice and how prey divergence may have evolved within the group.

The tribe Bembicini includes 17 genera, two of which contain single species of unknown behavior. Of the remaining genera, two (Microbembex and Bicyrtes) form a lineage that has diverged from the main stock of the tribe (Bohart \& Menke 1976). Although these genera are interesting in their own ways, they will not be considered here. The remaining 13 genera form a monophyletic group that includes the large, cosmopolitan genus Bembix and 12 other, smaller genera that are confined to the Americas.

Most of the existing data on prey choice are presented in tabular form (Tables 1-4). It must be pointed out that the data are very uneven. In some cases, information is derived from study of a single nest; in other cases, species have been studied at numerous sites and by several researchers. Many species of Bembicini have not been studied at all; knowledge of these might well alter any conclusions reached here.

Summarizing the data from the tables: of the 132 species of the 13 genera considered here, $100(76 \%)$ are recorded as preying only on Diptera (Table 1), $11(8 \%)$ as preying on Diptera with some use of insects other than Diptera (Tables 2 and 3), and $21(16 \%)$ as preying not on Diptera but on other kinds of insects (Table 4). Those that prey on Diptera but have been found to also use other insects may use: Lepidoptera, Hymenoptera, Neuroptera, Odonata, and/or Homoptera (rarely Heteroptera). Those that do not prey on Diptera at all (so far as known) prey on insects of these same orders (Fig. 1). Notably absent are three very prevalent groups, Coleoptera, Orthoptera, and Lepidoptera larvae, although these groups comprise the major prey of other taxa of Sphecidae. Presumably members of these groups are too sessile, cryptic, or well defended to be readily encountered by aerial predators such as Bembicini.

\section{Bembicini as Fly Predators}

Diptera used as prey by Bembicini are robust flies (suborder Brachycera rather than Nematocera). Within these groups, a wide variety of flies may be taken. For example, flies of 12 families are recorded for Bembix nubilipennis Cresson (Evans 1966). Nevertheless individual females often appear to specialize on certain kinds. For example, in an aggregation of $B$. sayi Cresson in Florida, where flies of seven families were taken as prey, two nests were stocked almost entirely with horse flies of one species (Chlorotabanus crepuscularis Bequaert), while a nearby nest contained 10 asilid flies plus one bee fly (Evans 1966). Glenostictia pictifrons (Smith) made use of flies of seven families at a site in Kansas; but several females made repeated use of the nemestrinid fly Neorhynchocephalus volaticus (Williston), which they evidently captured from a patch of mint (Alexander et al. 1993). Clearly individuals do learn sources of prey and return repeatedly to these sources.

Different populations of one species often appear to exhibit quite different choices of prey. For example, nests in an aggregation of Bembix americana spinolae Lepeletier in Wyoming were stocked $80 \%$ with deer flies of the genus Chrysops, while nests of this species in New Mexico were stocked wholly with bee flies (Bombyliidae) (Evans 1966). Genise (1980) noted an aggregation of Rubrica nasuta (Christ) in Cordoba, Argentina, that provisioned extensively with Stratiomyidae, especially Hermetia species, which they evidently captured on nearby patches of flowers. On the other

Table 1. Bembicini that prey only on flies (so far as known) 1, 2.

Hemidula, 2 spp. (NT). Genise 1982a, 1989.

Rubrica, 2 spp. (NT). Genise 1980, 1982b; Pimenta \& Martins 1999.

Selman, 1 sp. (NT). Evans \& Matthews 1974, Genise 1981b.

Stictia, 9 spp. (NA, NT). Evans 1966; Evans \& Matthews 1974; Genise 1981 a, 1982c; Matthews et al. 1981; Post 1981; Sheehan 1984.

Trichostictia, 2 spp. (NT). Genise 1981b, 1985.

Glenostictia, 4 spp. (NA). Gillaspy et al. 1962, Alcock 1975, Alexander et al. 1993.

Steniolia, 6 spp. (NA, NT). Evans \& Gillaspy 1964, Larsson 1990.

Bembix, 74 spp.

18 spp. (NA, NT). Evans 1957, 1966; Evans \& Matthews 1974; Genise 1982d; Kimsey et al. 1981.

21 spp. (PA, OR). Nielsen 1945; Tsuneki 1956-58, 1969; Asis et al. 1992; Krombein \& Van der Vecht 1987.

18 spp. (AF). Gess 1986, Gess \& Gess 1989.

17 spp. (AU). Evans \& Matthews 1973, Evans et al. 1982.

${ }^{1} \mathrm{AF}=$ Africa, $\mathrm{AU}=$ Australia, $\mathrm{NA}=$ Nearctic, $\mathrm{NT}=$ Neotropical, $\mathrm{OR}=$ Oriental, $\mathrm{PA}=$ Palaearctic.

${ }^{2}$ Only major references are cited. 
Table 2. Bembicini that prey on flies but have occasionally been found to use non-dipterous prey.

1. Rubrica nasuta (Christ) (NT)

There are many records of this widely distributed species preying on Diptera (Genise 1980, Pimenta \& Martins 1999). Evans et al. (1974) presented data from Trinidad of a female carrying a skipper. In Argentina, one nest was found to contain the wings of a skipper (with flies), another nest the wings of two moths.

2. Zyzzyx chilensis (Eschscholz) (NT)

This species is a fly predator (Janvier 1928, Genise 1982e). However, Janvier found a skipper (Hesperiidae) in one nest, apparently taken as prey.

3. Bembix melanaspis Parker (NA)

Alcock \& Gamboa (1975) studied this species in Arizona and found it preying on flies of five different families. In one nest cell they found the wings of a damselfly (Odonata).

4. Bembix citripes Taschenberg (NT)

This species is well known to be a predator on flies (Evans \& Matthews 1974, Genise 1982d). Llano (1959) also reported the species to be a fly predator, but he found a small bee in one nest.

5. Bembix littoralis Turner (AU)

Evans and Matthews (1973) obtained 231 records of diverse flies taken as prey by this widely distributed species. In a single nest containing a partly grown larva they found 14 flies, parts of other flies, and a single stingless bee (Trigona).

6. Bembix variabilis Smith (AU)

This species is widely distributed in Australia. Evans \& Matthews (1973) reported it as preying on flies at 10 localities in diverse parts of the continent. However, at sites in the North nests contained many damselflies (Coenagrionidae) and females were frequently seen carrying these insects. Further discussion in text.

7. Stictia carolina (Fabricius) (NA)

There are many records of this species preying on flies (Evans 1966). Lin (1971) found some females at a site in Oklahoma preying on small cicadas and on skippers. Most cells he excavated contained only flies, but four contained cicadas and one skipper (along with flies). Hook (1981), working in New Jersey, found Diptera in all nine nests he excavated, but four also contained skippers or their remains. Further discussion in text.

hand, an aggregation in the state of Buenos Aires preyed primarily on Eristalis (Syrphidae) during January and February, but a few weeks later, when syrphid flies were less abundant, nests were provisioned almost exclusively with Tabanidae.

Unfortunately little research has been done on prey capture by these wasps. There are many anecdotal accounts of prey capture at flowers, at garbage or manure, or from the bodies of livestock or people. Philippi \& Eberhard (1986) showed that females of Stictia signata (Linnaeus) prefer to hunt horse flies on persons wearing dark rather than light clothing. They further found that freshly killed horse flies of two species, when impaled on twigs, were readily hit by female Stictia. Short $(7 \mathrm{~mm})$ black, wooden cylinders, when held against the legs of a person, were readily struck by the wasps, but longer $(14 \mathrm{~mm})$ or tan-colored models were mostly ignored. Only when a tan model was tapered and painted dark above and with green eye spots (like a horse fly) did it elicit a response.

In his studies of prey capture by the beewolf Philanthus triangulum (Fabricius), Tinbergen (1935) found that females pursued any moving object of about the right size, but capture involved receipt of a scent from the bee and stinging required tactile stimuli. Considering the great diversity of prey taken by Bembicini, even by individual females, it is hard to believe that chemical stimuli play an important role. Also, disparity in body form among the prey of some species suggests that tactile stimuli may be of importance primarily for guiding the sting to the thorax of the prey.

\section{Use of Prey Other than Flies}

If we assume that the ancestral bembicine wasp was a fly predator, then special attention must be paid to species that use flies but occasionally use insects of other orders (Table 2 ). When such predation is very infrequent, it is sometimes assumed that an "error" had occurred. For example, in discussing $R$. nasuta, Evans et al. (1974) believed that four records of the use of unusual prey (skippers, moths, dragonflies) might be "mistakes," that is, "the wasps struck them in the course of fly-hunting and for some reason failed to discriminate them from the more usual prey." Such occasional departures from the usual prey raise questions that should not be so easily dismissed.

Concerning Bembix variabilis Smith, Evans \& Matthews (1973) found that throughout its broad range females used 
Table 3. Fly predators that also make regular use of insects of other orders.

8. Glenostctia scitula (Fox) (NA)

This species occurs in deserts from Texas to California. Evans (1966) reported on prey from three sites in Western Texas. Diptera were used in some numbers at all three sites. Hymenoptera were also used at all three sites, Homoptera at two (Cicadellidae, Psyllidae), Heteroptera at two (Miridae). Hymenoptera included Braconidae, Torymidae, Formicidae, Sphecidae, Colletidae, Andrenidae, and Halictidae. The andrenid genus Perdita made up 85 of a total of 167 prey, or $51 \%$. A few nests contained only flies, many contained mostly or wholly Perdita, and several contained a mixture of three orders. Other species of this genus, so far as known, prey only on Diptera.

9. Bembix moma Evans \& Matthews (AU)

This is a widely distributed species that was studied by Evans \& Matthews (1973) at seven localities. A nest in Victoria was found to be provisioned with wasps and bees (Tiphiidae, Sphecidae, Colletidae, and Halictidae). More detailed studies in Northern Australia found the prey to consist of Diptera of six families and Hymenoptera of eight families, besides the above Ichneumonidae, Gasteruptiidae, Pompilidae, and four male Trigona (Apidae). Overall, of 391 prey records, flies made up $7 \%$, wasps $19 \%$, and bees $74 \%$. The majority of bees belonged to the genera Hylaeus and Homalictus.

10. Bembix kamulla Evans \& Matthews (AU)

This is a wasp of the dry interior, studied by Evans et al. (1982) at a site in New South Wales, where it was fairly common. Of 21 intact prey taken from nest cells, four were flies of the family Asilidae, the remaining 17 antlions (Myrmeleontidae) of four species. The egg was found to be laid on the side of a fly (in the common Bembix manner) and in two cases on the side of an antlion.

11. Bembix allunga Evans \& Matthews (AU)

This is a species of coastal and near-coastal localities in the northern half of the continent. Evans et al. (1982) studied the species at a site in New South Wales and a site in Queensland. Prey consisted of Diptera of three families (Tabanidae, Bombyliidae, and Asilidae), Neuroptera of three families (Ascalaphidae, Chrysopidae, and Myrmeleontidae), Odonata of the family Libellulidae, and Homoptera represented by the hind wing of a cicada in one cell. The egg was found to be laid on the side of a fly (four examples) or an antlion (one example). Overall, of 45 prey, $61 \%$ were Diptera, $30 \%$ Neuroptera, $7 \%$ Odonata, and 2\% Homoptera.

flies of 14 families. During the dry season in Northern Australia, females nested along watercourses and took flies associated with water, especially Ephydridae. At two sites near Darwin, nest cells contained both flies and damselflies (Odonata). At a site along the Ord River, in extreme northeastern Western Australia, several females were seen carrying damselflies, and three nests excavated there contained nothing but damselflies (several species of Coenagrionidae). Evidently about 23 damselflies sufficed to bring a larva to maturity, as compared to 50 or more flies. Whether or not damselflies continue to be used outside of the dry season remains to be determined.

The case of Stictia carolina (Fabricius) is somewhat different. Lin (1971) studied a large aggregation in Oklahoma in which females preyed on muscoid flies as well as the large horse fly Tabanus sulcifrons Macquart, the latter being used especially during the last two or three days of provisioning. Of 20 nest contents he analyzed, all contained Tabanus and many contained smaller flies or their remains; but four contained small brown cicadas (Homoptera: Melampsalta calliope Walker) (two to four per cell) and one contained two skippers (Lepidoptera: Atalopedes campestris Boisduval). Six additional cicadas and four skippers were taken from females as they returned to their nests. Use of skippers was confirmed by Hook (1981), who found four of nine nests in New Jersey to contain both flies and skippers.
Lin believed that the use of unusual prey "may have been the result of competition for larval food in this dense population."

From these examples we move to species that regularly use insects of other orders in addition to Diptera (Table 3). Clearly these species have evolved the ability to respond to a diversity of insects besides flies: sucking bugs, wasps, bees, antlion adults, and, in one case, dragonflies. The North American Glenostictia scitula (Fox) nests in barren deserts where Perdita bees may be far more readily available than flies. The Australian Bembix kamulla Evans \& Matthews is also an inhabitant of arid places where antlions may be more plentiful than flies at certain times. It is more difficult to explain the advantages gained by B. moma and B. allunga, both of which nest in areas where flies appear plentiful. Both share nesting sites with species that are strictly fly predators; perhaps they achieve some release from competition by having broadened their selection of prey.

Finally, we are left with an array of 21 species of five genera that do not prey on Diptera but exploit other prey (Table 4). That the groups of non-dipterous prey are the same as those used by species that also use flies is suggestive. Evidently there is something about the five groups shown in Fig. 1 that, very broadly, satisfies the sensory equipment and flight capacities of wasps that probably evolved originally as fly predators. 
Table 4. Bembicini that make regular use of prey other than Diptera.

12. Editha, 4 spp. (NT)

Studies by Genise (1981b) in Argentina on E.integra (Handlirsch) and by Martins (1993) in Brazil on E.magnifica (Perty) confirm the use of Lepidoptera as prey. Brief published notes on E. adonis (Handlirsch) and E. fuscipennis (Lepeletier) also indicate use of Lepidoptera. Families used include Nymphalidae, Satyridae, Pieridae, Erycinidae, Libytheidae, Papilionidae, and Hesperiidae. Martins (1993) also recorded two sphingid moths.

13. Stictiella, 6 spp. (NA)

Members of this genus occur throughout much of North America, and all published reports indicate use of moths and butterflies as prey. Moths belong to the families Noctuidae, Pyralidae, Olethreutidae, and Gelechiidae, butterflies belong to Libytheidae, Nymphalidae, Lycaenidae, and Hesperiidae. Some species, such as S. formosa (Cresson) appear to take only butterflies, others, such as S.emarginata (Cresson) only moths; other species use a mixture (Gillaspy et al. 1962, Alcock \& Gamboa 1975).

14. Microstictia texensis Gillaspy (NA)

Only one of the 10 species in this genus has been studied. M. texensis was found to prey on diverse small moths in Southern Texas. Families included Geometridae, Gelechiidae, Olethreutidae, Pterophoridae, and Pyralidae (Gillaspy 1983).

15. Xerostictia longilabris Gillaspy (NA)

The single species of this genus is confined to deserts of the Southwestern United States and Northern Mexico. Alcock (1975) found two nests in Southern Arizona. Both had cells that were stocked with a mixture of adult antlions (Brachynemurus longipalpis Hagen) and flatid bugs (Ormenis saucia Van Duzee).

16. Bembix regnata Parker (AF)

Benson (1934) reported on observations by R.H.R. Stevenson in Southern Rhodesia (now Zimbabwe), indicating that this species (in contrast to many other fly-predator Bembix in Africa) preys on butterflies: Pieridae, Nymphalidae, and Hesperiidae. Gess (1986) has examined Stevenson's material in the British Museum. Other reports of Lepidoptera use by African Bembix may or may not apply to this species.

17. Bembix stenebdoma Parker (NA)

A single nest of this species, discovered in central New Mexico, had a cell that contained 10 lacewings (Chrysopidae), with an egg on the side of one of them. The lacewings belonged to three species of the genera Eremochrysis and Chrysoperla (Evans 1978).

18. Bembix thooma Evans \& Matthews (AU)

This species was studied at two widely separated sites in the Australian interior. Three nests were stocked entirely with male thynnine wasps (Tiphiidae, Thynninae), tentatively identified as belonging to the genera Aspidothynnus and Thynnoturneria. The egg was laid on the side of one of the wasps. It is probable that the unusual modifications of the sternites of the female represent an adaptation for carrying the unusual prey (Evans \& Matthews 1973).

19. Bembix tuberculiventris Turner, B. flavipes Smith, and B. musca Handlirsch (AU)

These three small, closely related species are widespread in Australia and not uncommon. All have been atudied in diverse localities and found to be predators on bees. B. tuberculiventris takes both solitary bees (Colletidae and Halictidae) and social bees (Trigona, Apidae). B. flavipes was found, in three widely spaced localities in Northern Australia, to prey only on Trigona essingtoni Cockerell, while B. musca was found in five localities to prey only on T. carbonaria Smith. The Trigona were nearly all males and are believed to have been captured at male swarms that form outside hives. The last two species are among the most host specific of any solitary wasps. It is noteworthy that true beewolves (Philanthus) do not occur in Australia; to a degree these Bembix species may be said to fill this ecological niche (Evans \& Matthews 1973).

20. Bembix coonundura Evans \& Matthews (AU)

This species is known from only a few localities in Western Australia. Wheeler \& Dow (1933) reported the species preying on damselflies (Odonata) at Lake Violet, which was filled at the time of their visit. Evans \& Matthews (1973) visited the site when the lake was dry; damselflies were not active, but they dug cocoons from the soil from which members of this species were readed (the cocoons were surrounded by damselfly wings). The damselflies were Coenagrionidae (Xanthagrion erythroneurum Selys) and Lestidae (Austrolestes annulosus Selys).

21. Bembix minya Evans \& Matthews (AU)

This inhabitant of Southeastern Australia is closely related to the preceding and has been found to prey on four species of damselflies (Coenagrionidae and Lestidae) (Austin 1999). Five nests yielded a total of 79 damselflies, averaging 16 per nest cell. Damselflies were evidently being taken at farm ponds 200-600 $\mathrm{m}$ away. No prey other than damselflies were found in the nests. 


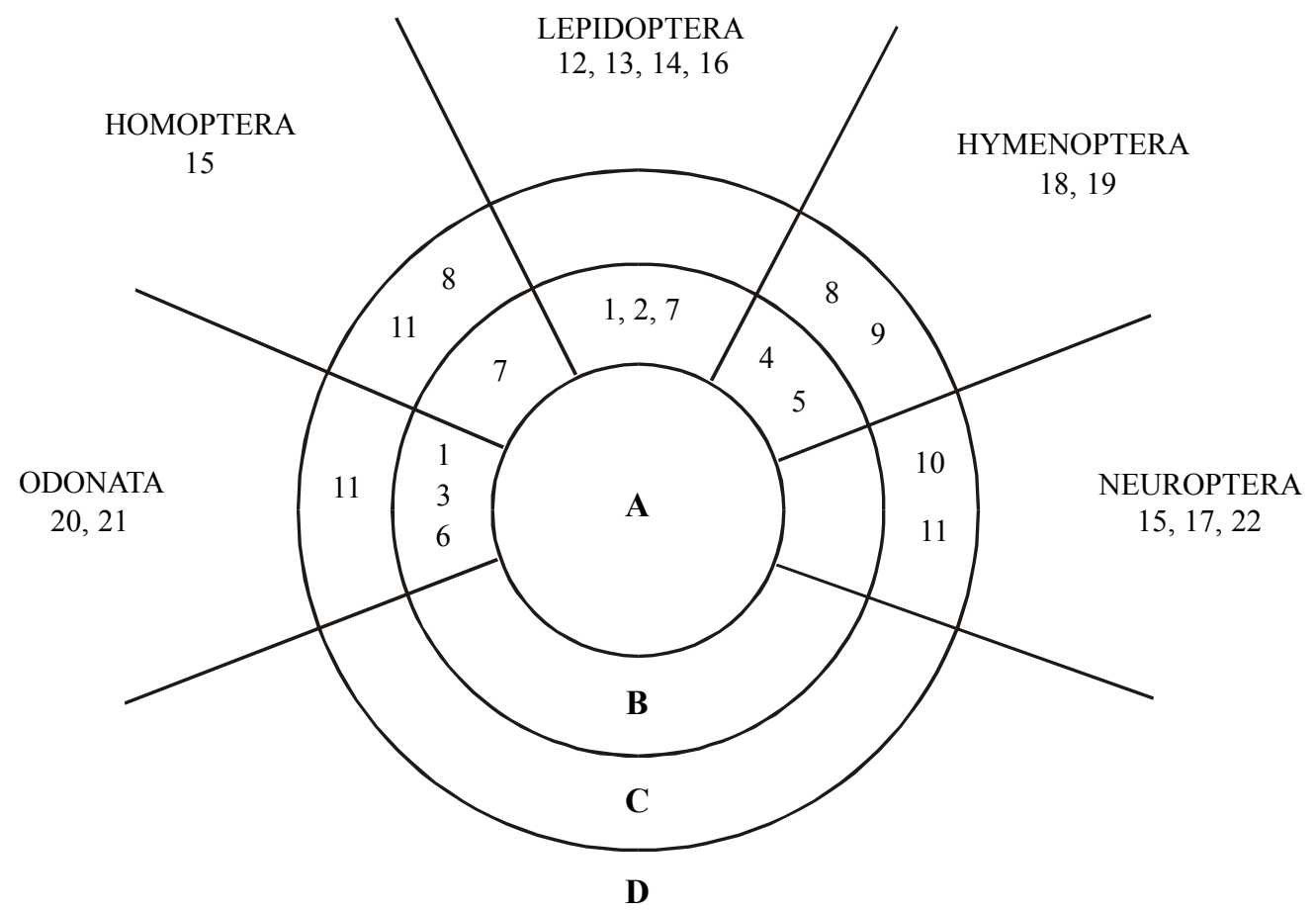

Figure 1. Diagram of prey use by diverse Bembicini. Letters refer to the four tables, as follows: A. Exclusive use of Diptera (so far as known) (Table 1); B. Diptera but occasional use of non-dipterous prey (Table 2); C. Diptera predators that regularly use non-dipterous prey (Table 3); D. Bembicini that regularly use prey other than Diptera (Table 4). Numbers refer to individual items in Tables 1-4.

This is in spite of the fact that slender insects with elongate wings, such as damselflies and antlions, have a very different body form from flies. Yet both Odonata and Neuroptera are used as prey by five or six taxa, either occasionally or regularly. Butterflies or moths are used by seven taxa. These, too, have body forms very different from flies; not only are their wings broad, but body and wings are covered with scales. Yet these seemingly very different, unfly-like insects are handled readily by some bembicine wasps. Prey is held in flight by the middle legs, as in all Bembicini. The long bodies of damselflies extend well behind the wasp's body, and the wings of moths and butterflies are folded down and dangle well below the wasp's body. As the wasp enters the nest, the wings of butterflies are folded backward, and in the nest the larva and cocoon come to be surrounded by the uneaten wings of the prey (Martins 1993). The vast majority of sand wasps lay their egg on the first prey placed in the cell, erect on the wing-base and close to the side of the thorax. Predators on Odonata, Neuroptera, and Lepidoptera lay the egg in a very similar manner despite the great difference in body form. Oviposition, like other details of behavior, is obviously sufficiently labile to accomodate to these diverse body forms.

\section{Discussion}

Presumably, most if not all species differentiated in isolation, where each came to exploit prey items plentiful in that area. When barriers disappeared and related species shared nesting sites, any tendencies to hunt at different places or to respond to different images would be reinforced. Digger wasp species do often share nesting sites, since areas of bare, sandy soil are often a limited resource. In their studies of Australian Bembix, Evans \& Matthews (1973) reported four species of that genus sharing some nesting sites. Under these conditions, any species that evolved the ability to make use of an alternative source of prey might be at an advantage, since there are only so many flies in any habitat.

Possible stages in the divergence from fly predation are suggested by species listed in the tables. Specialists on Diptera (Table 1; Fig. 1A) use a great diversity of flies, including elongate flies such as Asilidae. Under certain conditions, some species occasionally take non-dipterous prey (Table 2; Fig. 1B) and some have evolved further by broadening the range of prey that they regularly use (Table 3; Fig. 1C). Finally, some species once again became specialists, but on members of groups that had also been used by members of the preceding two groups (Table 4; Fig. 1D).

That sand wasps learn sources of prey and return repeatedly to these sources is well known (examples cited above). Females providing prey for larvae in a nest, or bearing a mature oocyte and having just finished digging a nest, are under pressure to find food quickly. Under situations of scarcity of the usual prey, as a result of climatic factors or competition from other species, females may undergo a lowering of the threshold of response or - to put it another way - a broadening of sensory focusing on images of a certain size - such that alternate prey are seized and utilized. 


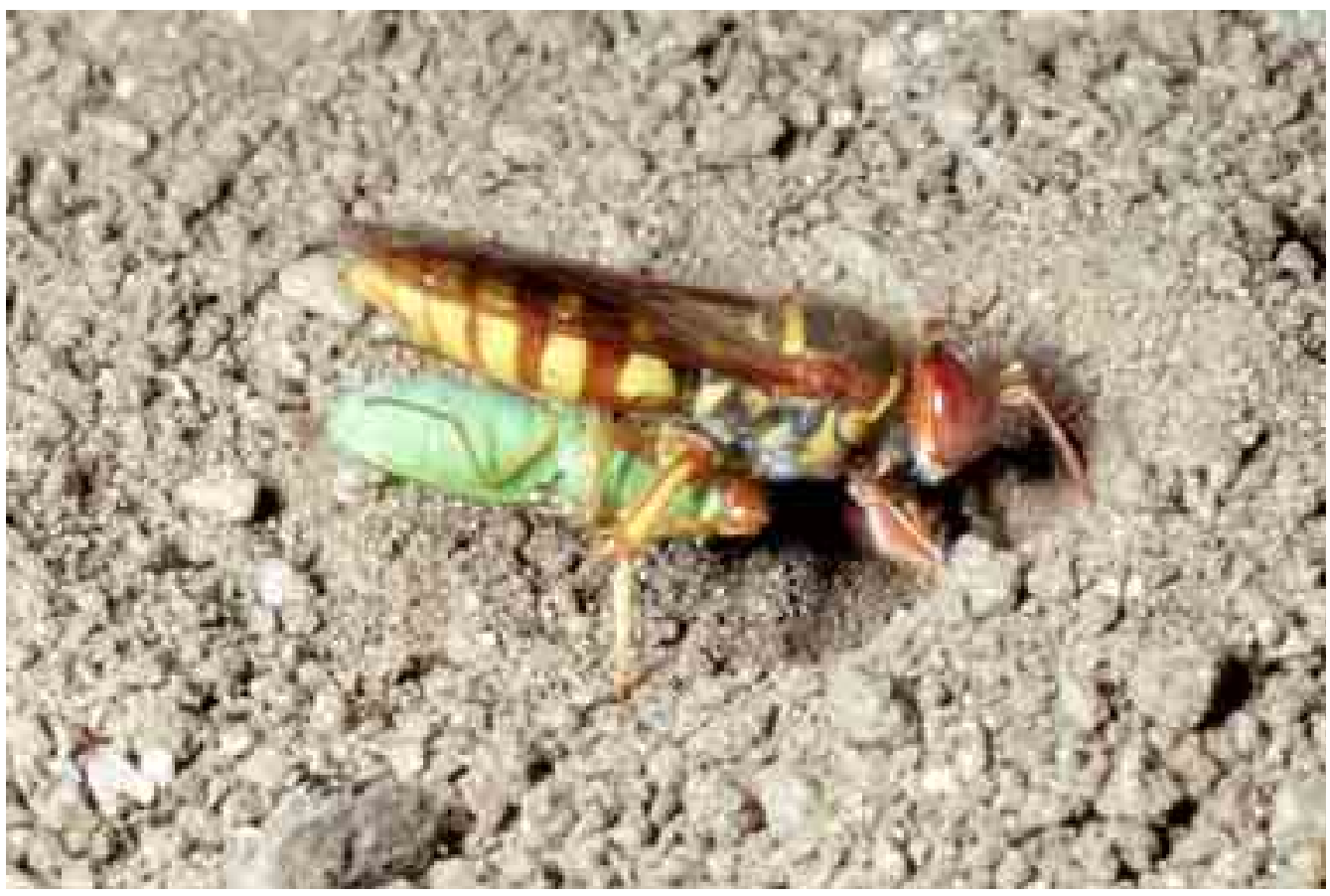

Figure 2. Rubrica nasuta female taking a fly (Stratiomyidae) into her nest (Colombia). Some individuals of this species have been found to occasionally use Lepidoptera and Odonata as prey.

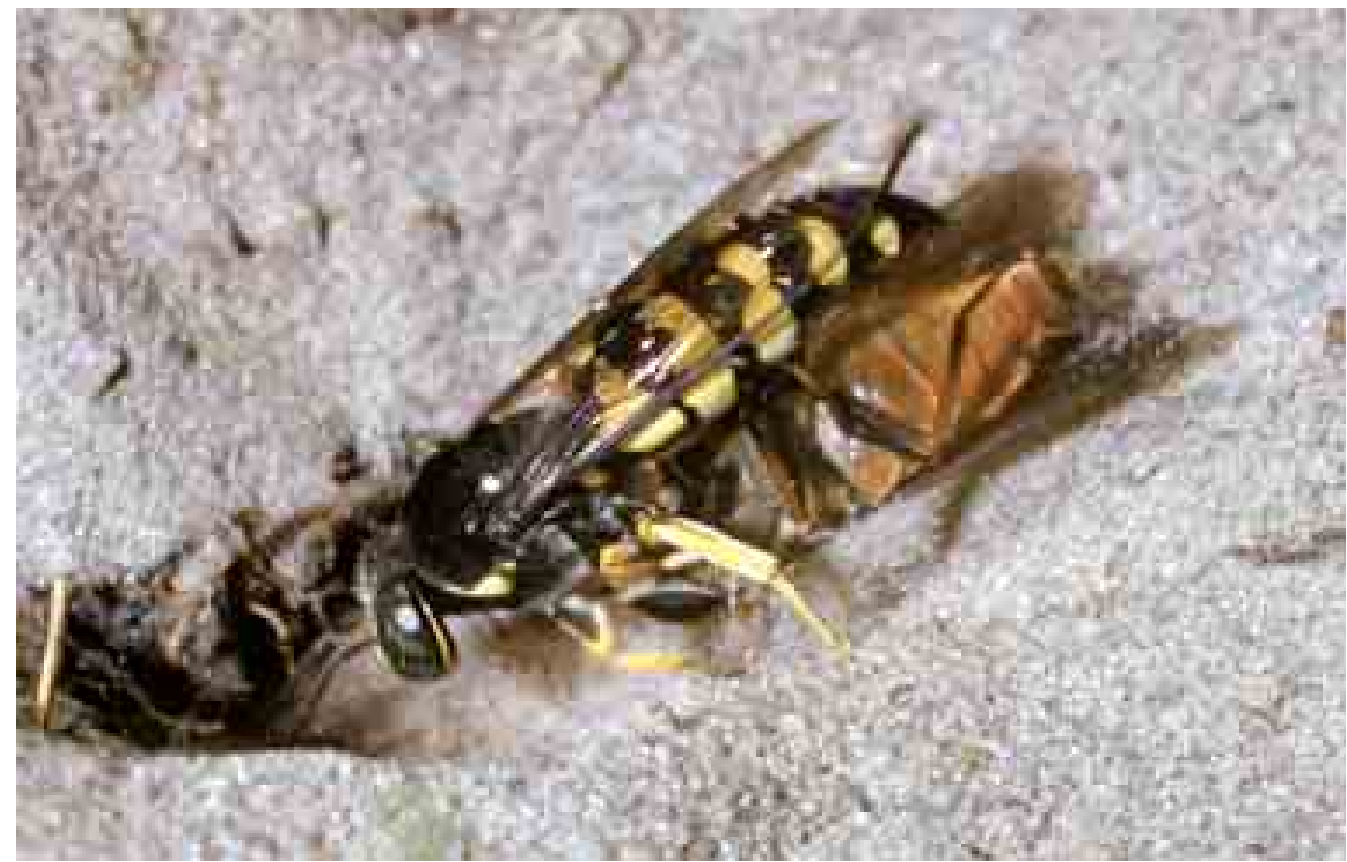

Figure 3. Stictia carolina female taking a horse fly (Tabanidae) into her nest (U.S.A). Some populations of this species use skippers (Lepidoptera) and cicadas (Homoptera) as prey.

There are costs to increased searching time and decisionmaking (Bernays \& Wcislo 1944). Not only is energy wasted, but wasps are exposed to predation and unattended nests are exposed to entry by nest parasites such as Mutillidae (or to conspecific nest robbers, as has been reported fairly frequently, e.g., Sheehan 1984). In extreme cases, larvae may starve. 


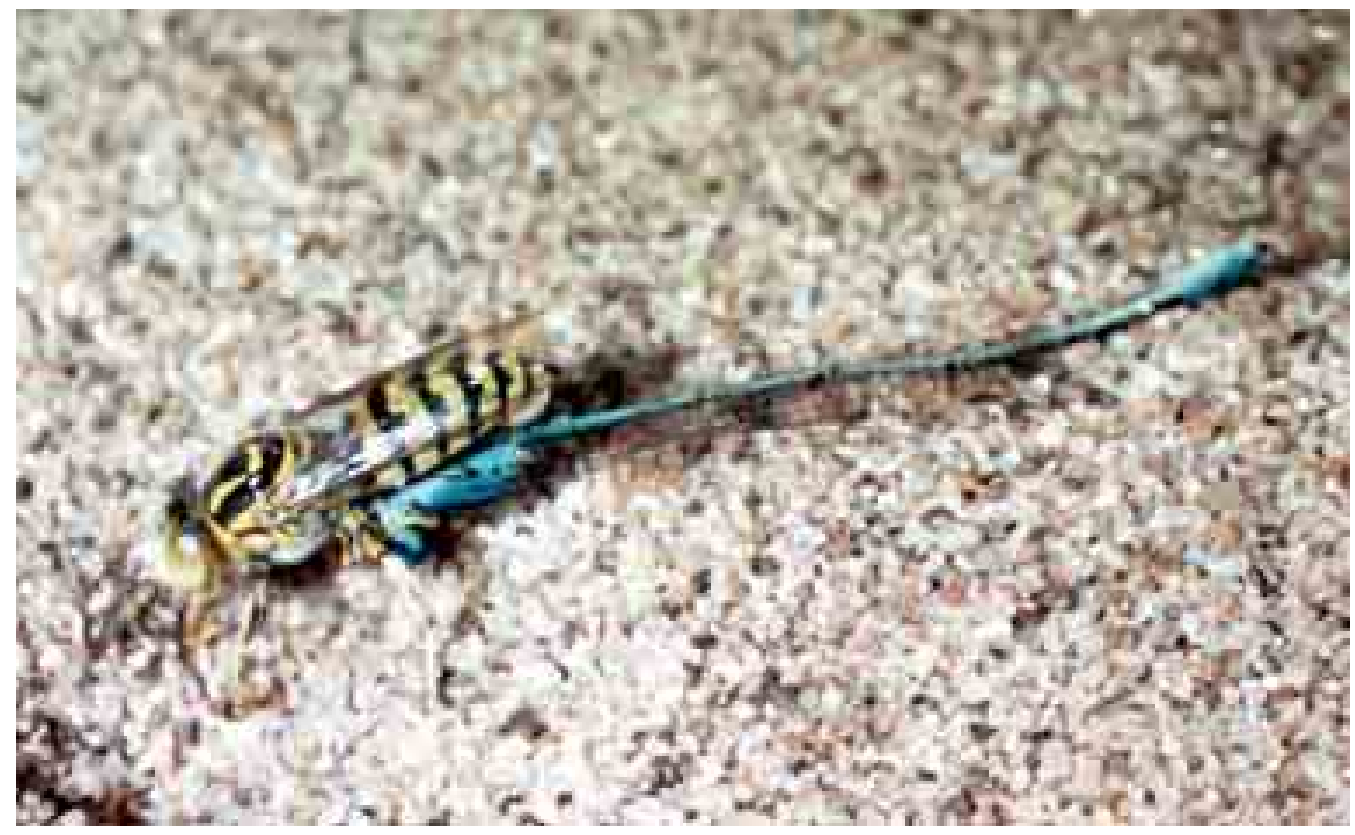

Figure 4. Bembix variabilis, a female taking a damselfly (Odonata) into her nest (Australia). In most parts of its range, this species uses Diptera as prey.

It is known that some parasitoid wasps will oviposit on an alternative host when they do not have access to the usual host. Thorpe (1931) provided several examples in which "biological races" resulted when a species was deprived of its usual host and moved to another host more or less permanently. Fitt (1986) deprived fruit flies of the genus Dacus of their usual hosts for several days; one species, $D$. tryoni Froggatt, laid eggs on an alternate host readily after four days, with no diminution in the number of eggs laid. This example involved a plant feeder using chemical cues, but the principal is the same.

Much has been written concerning "switching behavior", that is, the ability of a predator to attack an abundant prey in numbers disproportionately more often than would be expected by chance encounters. If another prey becomes more abundant, the predator may switch its attacks disproportionately to the new prey (Cornell 1976). Formation of a new search image with respect to certain sensory cues may enhance a predator's efficiency; but flexibility in search image formation may also be important, especially in a highly variable environment. When animals are repeatedly stressed by scarcity of prey, new search images may be "crystallized" (Rau 1933) or "genetically assimilated" (Waddington 1960) through selection for genes reinforcing such prey selection. A shift to a new host may involve only minor alterations in the genome (Bush 1975). The idea that "learned behavioral adaptations may commonly precede innate forms of the same behaviors" is well defended by Tierney (1986) and applied to responses to chemical signals in social wasps by Jeanne (1996). Wcislo (1989) has stressed the importance of behavioral adaptability in inducing evolutionary change in feeding behavior, host selection, and even in morphology.

There is still much to be learned concerning the behavior of Bembicini. Studies of many species remain fragmentary and incomplete, and there are many species that have not been studied in the field. There is much room for experimental work using techniques similar to those used by Philippi \& Eberhard (1986). It should be possible to rear these insects in greenhouses or other large, enclosed spaces where prey availability can be manipulated. Until such research can be undertaken, scenarios based on observations made in the field pose intriguing questions but can only suggest tentative answers.

\section{Acknowledgments}

I have profited from the useful comments of several leading researchers on the behavior of sand wasps: Robert W. Matthews, University of Georgia, U.S.A.; Rogério P. Martins, Universidade Federal de Minas Gerais, Belo Horizonte, Brazil; and P.G. Willmer and Simon Potts, University of St. Andrews, United Kingdom. The comments of two anonymous reviewers are also much appreciated. My own field research, over many years, was supported by grants from the National Science Foundation, U.S.A.

\section{Literature Cited}

Alcock, J. 1975. The behavior of some bembicine wasps of southern Arizona (Hymenoptera: Sphecidae, Microbembex, Glenostictia, Xerostictia). Southwest. Nat. 20: 337-342. 
Alcock, J. \& G. Gamboa. 1975. The nesting behavior of some sphecid wasps of Arizona, including Bembix, Microbembex, and Philanthus. J. Arizona Acad. Sci. 10: 154-165.

Alexander, B.A., R.L. Minckley \& D. Yanega. 1993. Nesting biology of Glenostictia pictifrons (F. Smith) (Hymenoptera: Sphecidae: Bembicini). J. Kans. Entomol. Soc. 66: 108-120.

Asis, J.D., S.F. Gayubo \& J. Tormos. 1992. Data on the nesting behaviour of five European Bembix and descriptions of the mature larvae of $B$. merceti and $B$. rostrata (Hymenoptera, Sphecidae). Deut. Entomol. Zeitschr. 39: 221-231.

Austin, A.D. 1999. Use of Odonata as prey by sand wasps, Bembix spp. (Hymenoptera: Sphecidae). Aust. Entomol. 26: 77-82.

Benson, R.B. 1934. Bembix regnata Parker, preying on butterflies. Proc. Entomol. Soc. London 9: 75-76.

Bernays, E.A. \& W.T. Wcislo. 1994. Sensory capabilities, information processing, and resource specialization. Quart. Rev. Biol. 69: 187-204.

Bohart, R.M. \& A.S. Menke. 1976. Sphecid wasps of the world: A generic revision. Berkeley, University of California Press, 695p.

Brues, C.T. 1936. Aberrant feeding behavior among insects and its bearing on the development of specialized food habits. Quart. Rev. Biol. 11: 305-319.

Bush, G.L. 1975. Sympatric speciation in phytophagous parasitic insects, p. 187-206. In P.W. Price (ed.), Evolutionary strategies of parasitic insects and mites. New York, Plenum, 340p.

Cane, J.H. \& M.M. Miyamoto. 1979. Nest defense and foraging ethology of a neotropical sand wasp, Bembix multipicta (Hymenoptera: Sphecidae). J. Kans. Entomol. Soc. 52: 667-672.

Cornell, H. 1976. Search strategies and the adapative significance of switching in some general predators. Amer. Naturalist 110: 317-320.

Evans, H.E. 1957. Studies on the Comparative Ethology of Digger Wasps of the genus Bembix. Ithaca, N.Y., Cornell University Press, 248p.

Evans, H.E. 1962. A review of nesting behavior of digger wasps of the genus Aphilanthops, with special attention to the mechanics of prey carriage. Behaviour 19: 239-260.

Evans, H.E. 1966. The comparative ethology and evolution of the sand wasps. Cambridge, Harvard University Press, 526p.
Evans, H.E. 1973. Notes on the nesting behavior of Steniolia elegans (Hymenoptera: Sphecidae). Great Basin Natur. 33: 29-30.

Evans, H.E. 1978. A solitary wasp that preys upon lacewings (Hymenoptera: Sphecidae; Neuroptera: Chrysopidae). Psyche 85: 81-84.

Evans, H.E., M.A. Evans \& A. Hook. 1982. Observations on the nests and prey of Australian Bembix sand wasps (Hymenoptera: Sphecidae). Aust. J. Zool. 30: 71-80.

Evans, H.E. \& J.E. Gillaspy. 1964. Observations on the ethology of digger wasps of the genus Steniolia (Hymenoptera: Sphecidae: Bembicini). Am. Midland Naturalist 72: 257-280.

Evans, H.E. \& R.W. Matthews. 1973. Systematics and nesting behavior of Australian Bembix sand wasps (Hymenoptera, Sphecidae). Mem. Amer. Entomol. Inst. 20: $1-387$.

Evans, H.E. \& R.W. Matthews. 1974. Observations on the nesting behavior of South American sand wasps (Hymenoptera). Biotropica 6: 130-134.

Evans, H.E., R.W. Matthews \& E.M. Callan. 1974. Observations on the nesting behavior of Rubrica surinamensis (DeGeer) (Hymenoptera, Sphecidae). Psyche 81: 334-352.

Fitt, G.P. 1986. The influence of a shortage of hosts on the specificity of oviposition behaviour in species of Dacus (Diptera, Tephritidae). Physiol. Entomol. 11: 133-143.

Genise, J.F. 1980. Selección de presas en Rubrica nasuta (Christ) (Hymenoptera, Sphecidae). Ecosur 7: 15-18.

Genise, J.F. 1981a. Observaciones sobre el comportamiento de nidificación de Stictia arcuata (Burmeister) (Hymenoptera, Sphecidae). Physis (C)40: 15-17.

Genise, J.F. 1981b. Estudios sobre el comportamiento de Bembicini neotropicales II. Selman notatus (Tasch.), Trichostictia guttata (Tasch.) y Editha integra (Burmeister) (Hymenoptera, Sphecidae). Rev. Soc. Entomol. Argentina 40: 249-262.

Genise, J.F. 1982a. Estudios sobre el comportamiento de nidificación de Bembicini neotropicales V. Hemidula singularis (Taschenberg) (Hymenoptera, Sphecidae). Rev. Soc. Entomol. Argentina 41: 77-84.

Genise, J.F. 1982b. Comportamiento de desecho de presas en Rubrica nasuta (Christ) y revision de esta actividad en Sphecidae (Insecta, Hymenoptera). Physis (C)40: 101109.

Genise, J.F. 1982c. Estudios sobre el comportamiento de nidificación de Bembicini neotropicales III. Stictia 
flexuosa (Taschenberg) y algunas reflexiones sobre la diferenciación de nichos ecológicos en Bembicini (Hymenoptera, Sphecidae). Physis (C)41: 79-85.

Genise, J.F. 1982d. Estudios sobre el comportamiento de nidificación de Bembicini neotropicales IV. Bembix citripes (Taschenberg) (Hymenoptera, Sphecidae). Physis (C) 41: 93-96.

Genise, J.F. 1982e. Estudios sobre el comportamiento de nidificación de Bembicini neotropicales VI. Zyzzyx chilensis (Eschscholz) (Hymenoptera, Sphecidae). Rev. Soc. Entomol. Argentina 41: 289-298.

Genise, J.F. 1985. Estudios sobre el comportamiento de nidificación de Bembicini neotropicales VII. Trichostictia vulpina (Handlirsch) (Hymenoptera, Sphecidae). Physis (C)43: 1-4.

Genise, J.F. 1989. Estudios sobre el comportamiento de nidificación de Bembicini neotropicales IX. Hemidula burmeisteri Willink (Hymenoptera, Sphecidae). Rev. Soc. Entomol. Argentina 45:275-277.

Gess, F.W. 1986. Three new species of southern African Bembix, a new synonymy, and biological notes on other species of the genus (Hymenoptera: Sphecidae: Nyssoninae). Ann. Cape Province Mus. Nat. Hist. 16: 137-160.

Gess, S.K. \& F.W. Gess. 1989. Notes on the nesting behaviour in Bembix bubalis Handlirsch in southern Africa with emphasis on nest sharing and reaction to nest parasites (Hymenoptera: Sphecidae). Ann. Cape Province Mus. Nat. Hist. 18: 151-160.

Gillaspy, J.E. 1983. New taxa of bembicine Sphecidae (Hymenoptera). Southwest. Nat. 8: 279-291.

Gillaspy, J.E., H.E. Evans \& C.S. Lin. 1962. Observations on the behavior of digger wasps of the genus Stictiella (Hymenoptera: Sphecidae), with a partition of the genus. Ann. Entomol. Soc. Am. 55: 559-566.

Hook, A. 1981. Hesperiidae as prey of Stictia carolina. J.N.Y. Entomol. Soc. 89: 202-203.

Iersel, J.J.A. Van 1952. On the orientation of Bembix rostrata L. Trans. $9^{\text {th }}$ Internat. Congr. Entomol., Amsterdam 1: 393.

Janvier, H. 1928. Recherches biologiques sur les prédateurs du Chili. Ann. Sci. Nat. Zool. (10)11: 67-207.

Jeanne, R. 1996. The evolution of exocrine gland function in wasps, p. 144-160. In S. Turillazzi \& M.J. WestEberhard (eds.), Natural history and evolution of paper wasps. London, Oxford, 347p.

Kimsey, L.S., R.B. Kimsey \& C.A. Toft. 1981. Life history of Bembix inyoensis in Death Valley (Hymenoptera: Sphecidae). J. Kans. Entomol. Soc. 54: 665-672.

Krombein, K.V. \& J. Van der Vecht. 1987. Biosystematic studies of Ceylonese wasps, XVII: A revision of Sri Lankan and South Indian Bembix Fabricius (Hymenoptera: Sphecoidea: Nyssonidae). Smithsonian Contr. Zool. no. 451, 30p.

Larsson, F.K. 1990. Thermoregulation and activity patterns of the sand wasp Steniolia longirostra (Say) (Hymenoptera: Sphecidae) in Costa Rica. Biotropica 22: 65-68.

Lin, C.S. 1971. Bionomics of Stictia carolina at Lake Texoma, with notes on some neotropical species (Hymenoptera: Sphecidae). Texas J. Sci. 23: 275-286.

Linsley, E.G. 1958. The ecology of solitary bees. Hilgardia 27: 543-599.

Llano, R.J. 1959. Observaciones biológicas de insectos bonaerenses. Supl. Rev. Educ. Prov. Buenos Aires, no. XII, 136p.

Martins, R.P. 1993. The biology of Editha magnifica (Perty 1834) (Hymenoptera Sphecidae). Tropical Zool. 6: 109123.

Matthews, R.W., R.A. Saunders \& J.R. Matthews. 1981. Nesting behavior of the sand wasp Stictia maculata (Hymenoptera: Sphecidae) in Costa Rica. J. Kans. Entomol. Soc. 54: 249-254.

Miller, R.C. \& F.E. Kurczewski. 1975. Comparative behavior of wasps of the genus Lindenius (Hymenoptera: Sphecidae, Crabroninae). J. N.Y. Entomol. Soc. 83: 82120.

Nielsen, E.T. 1945. Moeurs des Bembex. Spolia Zool. Mus. Hauniensis 7: 1-174.

O’Neill, K.M. 2001. Solitary wasps: behavior and natural history. Ithaca, N.Y., Cornell University Press, 406p.

Philippi, T. \& W.G. Eberhard. 1986. Foraging behavior of Stictia signata (Hymenoptera: Sphecidae). J. Kans. Entomol. Soc. 59: 604-608.

Pimenta, H.R. \& R.P. Martins. 1999. The natural history of the neotropical sand wasp Rubrica nasuta (Christ 1791) (Hymenoptera Sphecidae) in Brazil. Tropical Zool. 12: 273-288.

Post, D.C. 1981. Observations on female nesting and male behavior of Stictia signata (Hymenoptera: Sphecidae) in Brazil. Rev. Biol. Trop. 29: 105-113.

Rau, P. 1933. The Jungle Bees and Wasps of Barro Colorado Island. Kirkwood, Missouri, privately published, 324p. 
Rothschild, M. \& T. Clay. 1961. Fleas, Flukes, and Cuckoos. London, Arrow Books, 304p.

Shaw, S.R. 1988. Euphorine phylogeny: the evolution of diversity in host-utilization by parasitoid wasps (Hymenoptera: Braconidae). Ecol. Entomol. 13: 323-335.

Sheehan, W. 1984. Nesting biology of the sand wasp Stictia heros (Hymenoptera: Sphecidae: Nyssoninae) in Costa Rica. J. Kans. Entomol. Soc. 57: 377-386.

Thorpe, W.H. 1931. Biological races in insects and their significance in evolution. Ann. Appl. Biol. 18: 406-414.

Tierney, A.J. 1986. The evolution of learned and innate behavior contributions from genetics and neurobiology to a theory of behavioral evolution. Anim. Learn. Behav. 14: 339-348.

Tinbergen, N. 1935. Uber die Orientierung des Bienenwolfes II. Die Bienenjagd. Z. Vergleich. Physiol. 21: 699-716.
Tsuneki, K. 1956-58. Ethological studies on Bembix niponica Smith, with emphasis on the psychobiological analysis of behavior inside the nest (Hymenoptera, Sphecidae). Parts I-III. Mem. Fac. Lib. Arts, Fukui University, ser. 2, 6: 77-172, 7: 1-116, 8: 1-78.

Tsuneki, K. 1969. Gleanings on the bionomics of the eastAsiatic non-social wasps (Hymenoptera). IV. Some species of Bembicini, Stizini, Gorytini, Mellinini, and Alyssonini. Etizenia, Biol. Lab. Fukui Univ. 11: 1-19.

Waddington, C.H. 1960. Evolutionary adaptation, p. 381402. In S. Tax (ed.), The evolution of life. Chicago, University of Chicago Press, 629p.

Wcislo, W.T. 1989. Behavioral environments and evolutionary change. Annu. Rev. Ecol. Syst. 20: 137169.

Wheeler, W.M. \& R. Dow. 1933. Unusual prey of Bembix. Psyche 40:57-59. 
